\title{
The Eastern Limit of Beringia: Mammoth Remains from Banks and Melville Islands, Northwest Territories

\author{
C.R. HARINGTON ${ }^{1}$
}

(Received 18 January 2005; accepted in revised form 8 April 2005)

\begin{abstract}
Two mammoth fossils (presumably woolly mammoth, Mammuthus primigenius) from northwestern Banks and southwestern Melville Islands, Northwest Territories, Canada, have been radiocarbon-dated to the Last Glacial Maximum (LGM), at 21000 and $22000{ }^{14} \mathrm{CYBP}$, respectively. These fossils not only are the northernmost mammoth records for North America, but also indicate that the Mammoth Steppe and Beringia extended eastward at least to Ballast Brook, Banks Island (74.3 ${ }^{\circ} \mathrm{N}$, $\left.123.1^{\circ} \mathrm{W}\right)$, and possibly to the Cape James Ross area of Melville Island $\left(75.7^{\circ} \mathrm{N}, 114.4^{\circ} \mathrm{W}\right)$. The specimens, a tibia and a tusk, probably represent woolly mammoths that moved northeastward from the Mackenzie Delta region during the LGM, when worldwide sea level had dropped about $120 \mathrm{~m}$, leaving large tracts of sea bottom exposed off the Beaufort Sea coast and the west coast of Banks Island (then largely clear of glacial ice). Evidently herb tundra rich enough to supply the mammoths' needs characterized the regional landscape at that time. It is proposed that the term "Beringia" be used in the broad sense where evidence exists for a land connection between Asia and North America, regardless of its cause(s) and its supposed westerly or easterly limits, and that "Beringia" be used in a standard way: followed by its geological age in parentheses. Also, the term "Bering Isthmus" seems preferable to the commonly used "Bering Land Bridge."
\end{abstract}

Key words: mammoth, Mammuthus primigenius, Last Glacial Maximum, Pleistocene, Beringia, Canadian Arctic Islands, Northwest Territories

RÉSUMÉ. Grâce à la datation au carbone 14, on a déterminé que deux fossiles de mammouths (probablement des mammouths laineux, Mammuthus primigenius) de l'île Banks au nord-ouest et de l'île Melville au sud-ouest, dans les Territoires du NordOuest, au Canada, remontent au dernier maximum glaciaire (DMG), soit à 21000 et à $22000{ }^{14} \mathrm{C} \mathrm{BP}$, respectivement. Non seulement ces fossiles représentent les restes de mammouths trouvés les plus au nord de l'Amérique du Nord, mais ils permettent également d'indiquer que la steppe à mammouth et la Béringie s'étendaient vers l'est tout au moins jusqu'à Ballast Brook, sur l'île Banks $\left(74,3^{\circ} \mathrm{N}, 123,1^{\circ} \mathrm{O}\right)$, et peut-être même jusqu'à la région du cap James Ross de l'île Melville $\left(75,7^{\circ} \mathrm{N}, 114,4^{\circ} \mathrm{O}\right)$. Les spécimens, soit un tibia et une défense, représentent probablement les restes de mammouths laineux qui se sont déplacés vers le nord-est à partir de la région du delta du Mackenzie pendant le DMG, lorsque le niveau de la mer à l'échelle planétaire avait baissé d'environ $120 \mathrm{~m}$, ce qui avait découvert de grandes bandes de fond marin sur la côte de la mer de Beaufort et sur la côte ouest de l'île Banks (qui n'avait à l'époque que peu de glace glaciaire). Il est évident qu'une toundra herbeuse assez riche pour subvenir aux besoins des mammouths caractérisait le paysage de la région à l'époque. On propose que le terme « Béringie » soit utilisé dans son sens large lorsqu'il existe des preuves selon lesquelles l'Asie et l'Amérique du Nord auraient été raccordés, sans égard à sa ou ses causes et à ses limites ouest et est présumées, et que « Béringie » soit employé de manière standard, c'est-à-dire qu'il soit suivi de son âge géologique entre parenthèses. Aussi, l'expression « isthme de Béring » semble préférable à l'expression « pont continental de Béring » couramment utilisée.

Mots clés: mammouth, Mammuthus primigenius, dernier maximum glaciaire, pléistocène, Béringie, archipel Arctique canadien, Territoires du Nord-Ouest

Traduit pour la revue Arctic par Nicole Giguère.

\section{INTRODUCTION}

G.M. Dawson (1894), a former director of the Geological Survey of Canada (1895-1901), was the first to make a solid case that water depths consistently less than 100 fathoms $(183 \mathrm{~m})$ throughout the northeastern half of the Bering Sea, as well as in Bering Strait and the Chukchi Sea, indicated those areas that are now part of the continental shelf. He reasoned that "in later geologic times more than once and perhaps during prolonged periods [there existed] a wide terrestrial plain connecting North America with Asia" (Dawson, 1894:144). Dawson (1894:133) also mentions that mammoths "must have found their way to the [Pribilof] Islands at a time when they were connected with the American continent by means of a wide plain ...."

In 1933, the geologist W.A. Johnston connected fluctuations in sea level with periods of glaciation, stating that "During the Wisconsin stage of glaciation, the general

${ }^{1}$ Canadian Museum of Nature (Paleobiology), P.O. Box 3443, Station D, Ottawa, Ontario K1P 6P4, Canada; dharington@ mus-nature.ca (C) The Arctic Institute of North America 
level of the sea must have been lower owing to the accumulation of ice on the land. The amount of lowering is generally estimated to have been at least 180 feet [ $55 \mathrm{~m}$ ], so that a land bridge probably existed during the height of the last glaciation" (Johnston, 1933:31). Johnston also speculated that mammoths and other Quaternary mammals crossed land connecting Siberia and Alaska.

Eric Hultén (1937), who first named Beringia (after the Danish-born explorer Vitus Bering; therefore, "Beringia" is pronounced with a hard "g"), concluded that it had been exposed as land during both the Riss/Illinoian and Würm/ Wisconsinan glaciations. He suggested that this vast Arctic lowland had been a refugium in which most Arctic and many boreal plant species were isolated during worldwide glacial epochs.

David M. Hopkins inspired, edited, and contributed to two important books concerning Beringia. Whereas The Bering Land Bridge (Hopkins, 1967) deals with aspects of Beringia sensu lato, Paleoecology of Beringia (Hopkins et al., 1982) focuses on the Late Pleistocene-specifically between the last (Eemian/Sangamonian) interglacial and the Early Holocene (about 8000 BP) (Hopkins, 1982). A clear, interesting chronological account of people who have contributed to the concept of Beringia is provided by O’Neill (2004:6-9).

Beringia has been described as a large (about 34 million $\mathrm{km}^{2}$ ) landmass comprising far eastern Russia and northwestern North America linked during glacial phases, when sea level became much lower, exposing land that connected the continents. The U.S. National Oceanographic and Atmospheric Administration (2004) in its Beringian Atlas home page states that Beringia reached and extended from east of the Lena River (about $140^{\circ} \mathrm{E}$ ) to northwestern Canada (about $130^{\circ} \mathrm{W}$ ), and Yurtsev's $(1974,1984)$ "Megaberingia" encompasses an area extending well west of the Kolyma River, and including to the east the Aleutian Archipelago and much of northwestern North America. Yurtsev (1984: Fig. 11) maps the area as extending roughly between longitudes $100^{\circ} \mathrm{E}$ and $90^{\circ} \mathrm{W}$ and latitudes $50^{\circ}$ and $78^{\circ} \mathrm{N}$. He believes that Megaberingian plants grew as a result of regular, constant floristic exchange between continental, oceanic, arctic, and boreal sources. The result, he states, is reflected in the present flora of the region, which is more complex, varied, and heterogeneous than that of other natural zones, and which exhibits distinct endemism.

In 1976, Sher (see Sher, 1984) used the term "Beringida" to designate the vast region that played a major role in the history of Beringian faunal exchange. He viewed it as an independent region in which a peculiar fauna evolved that repeatedly spread into Old and New worlds, proposing that "Beringia" be used for the narrow, active zone of Beringida in which the Bering Isthmus and Strait alternately appear. Sher (1997), in refining these concepts, states that Western Beringida includes the shelves of the East Siberian and Laptev seas extending from about Wrangel Island to the Taimyr Peninsula.
Other sources define Beringia as extending from the Kolyma River in Siberia to the Mackenzie River in Canada, including intervening continental shelf areas shallower than approximately $200 \mathrm{~m}$ (Matthews, 1982; Morlan, 1996). So neither the western nor the eastern limits of Beringia are clearly defined, although there is some support for a Kolyma-Omolon River boundary based on genetic studies of arctic hares, lemmings, tundra voles, and dunlins-a type of sandpiper (Waltari et al., 2004:596). Similarly, glaciation-induced genetic discontinuities along the Mackenzie River correspond to boundaries between Canadian Low Arctic and Beringian clades of the collared lemming (Dicrostonyx groenlandicus), as well as between different species of arctic hares (Lepus othus and Lepus arcticus) (Waltari et al., 2004).

However, from a zoogeographical viewpoint it is difficult to establish the western limits of this landmass because during the last glaciation, the core large mammal species that characterized it-e.g., woolly mammoth, steppe bison (Bison priscus), horse (Equus), caribou (Rangifer tarandus), and saiga (Saiga tatarica) — lived as far west as England, then a part of the Mammoth Steppe (Guthrie, 1990). Evidence for the presence of saiga antelope from Baillie Islands in the Late Pleistocene shows that the eastern limit of Beringia (and the Mammoth Steppe) extended well beyond the Mackenzie River to about $128^{\circ} \mathrm{W}$ (Harington, 1971, 1978, 1981; Harington and Cinq Mars, 1995). A circumpolar map (Fig. 1) shows places mentioned above and in the rest of the text, and Figure 2 shows Banks Island, Melville Island, and other Eastern Beringian Last Glacial Maximum (LGM; see Appendix 1) mammoth sites.

This paper provides (1) evidence for a new eastern limit to Beringia during the Last Glacial Maximum based on radiocarbon-dated mammoth fossils from northwestern Banks Island and southwestern Melville Island; (2) descriptions, photographs, radiocarbon ages, and available data on geological context for these fossils; (3) evidence for the geographic source of the mammoths concerned and their proposed northeastward route into what are now the western Canadian Arctic Islands; (4) a proposal that the term "Beringia" be used in the broad sense for the isthmus connecting Asia and North America regardless of refugium limits (unless they are well known), where possible giving its estimated geological age in a standard way.

\section{THE MAMMOTH SPECIMENS AND THEIR SOURCE}

Two specimens of mammoths from northwestern Banks Island and southwestern Melville Island (presumably from woolly mammoths, Mammuthus primigenius, since they are the northernmost Canadian records and date to the LGM) now indicate that the eastern limit of Beringia in the Late Wisconsinan should be placed even farther east than Baillie Islands. 


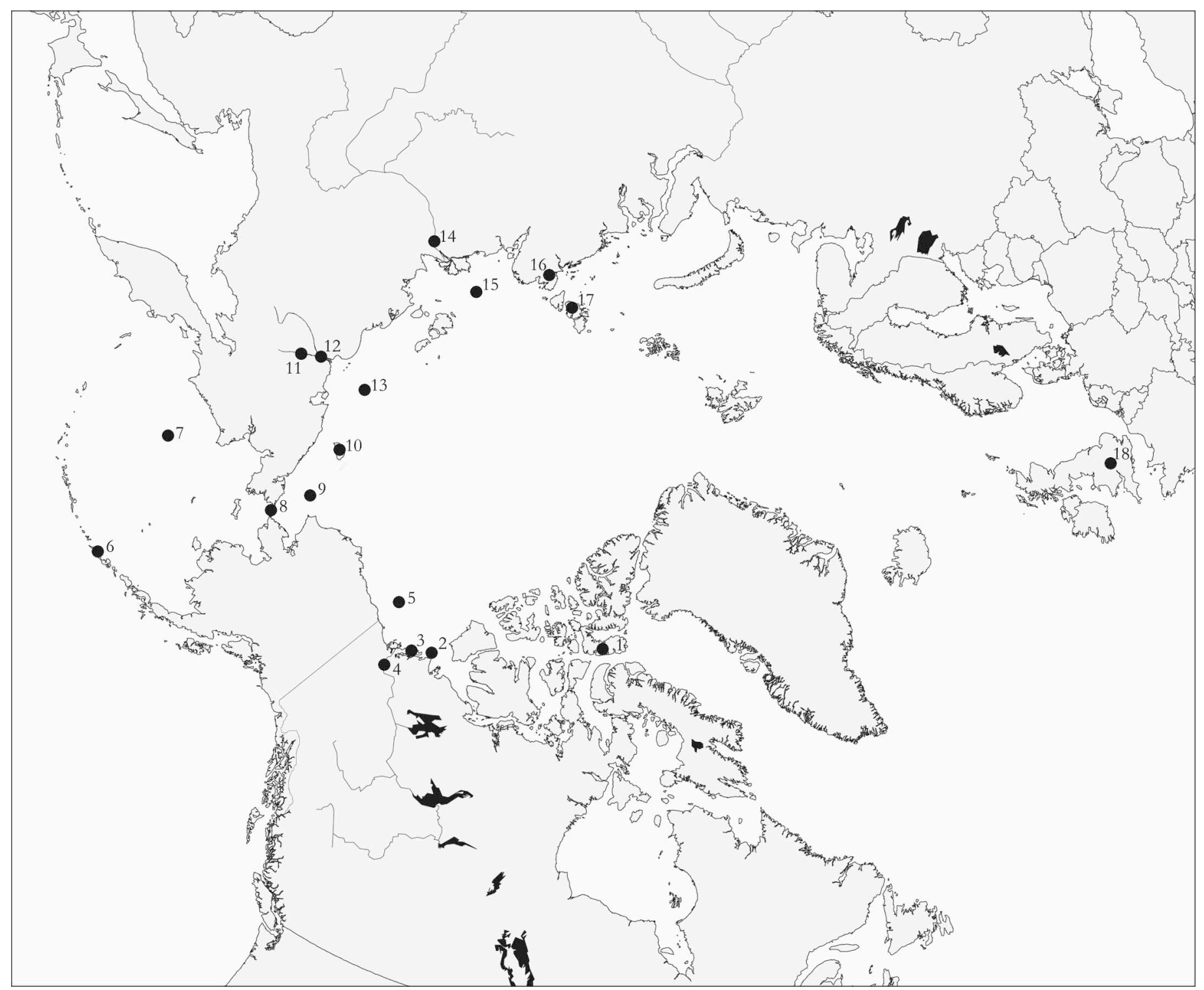

FIG. 1. Arctic circumpolar map showing places mentioned in the text, apart from those covered in Figure 2. Key: 1. Devon Island, Canada; 2. Baillie Islands, Canada; 3. McKinley Bay, Canada; 4. Mackenzie River, Canada; 5. Beaufort Sea; 6. Aleutian Islands, United States; 7. Bering Sea; 8. Bering Strait; 9 . Chukchi Sea; 10. Wrangel Island, Russia; 11. Omolon River, Russia; 12. Kolyma River, Russia; 13. East Siberian Sea; 14. Lena River, Russia; 15. Laptev Sea; 16. Taimyr Peninsula, Russia; 17. October Revolution Island, Russia; 18. England.

The first specimen (CMN 38655, Fig. 3) is a left tibia shaft fragment from the posteromedial region near midshaft, collected in 1976 by L.V. Hills. It was found in dark brown sand near the top (the upper metre of highly disturbed sediments) of a $36.6 \mathrm{~m}$ bluff near Ballast Brook, just north of the LGM moraine $\left(74.30^{\circ} \mathrm{N}, 123.08^{\circ} \mathrm{W}\right)$. As preserved, the specimen is $22 \mathrm{~cm}$ long $\times 10 \mathrm{~cm}$ wide, and it has been cut at the upper end to remove a radiocarbon sample. Hills (pers. comm. 1977, 2004) states that the animal represented by this specimen died inland, there being no chance that it was rafted ashore by sea ice from elsewhere. This fossil was radiocarbon-dated using Accelerator Mass Spectrometry (AMS) to $20700 \pm 270 \mathrm{BP}$ (T0-2355, normalized), indicating that mammoths lived on what is now northwestern Banks Island at the LGM. It is the second most northerly record in North America and has been mentioned by Harington (1990:143, 157).

The second specimen (Fig. 4) is part of a large tusk (91 cm long $\times 14.6 \mathrm{~cm}$ in diameter toward the base-part has since been removed for radiocarbon dating). Aarnout Castel (see Appendix 2) found the tusk (CMN 11833) on 14 September 1916, on a river bank inland from the camp of the Northern Party of the Canadian Arctic Expedition (1913 - 18), near Cape James Ross on Dundas Peninsula, Melville Island $\left(75.70^{\circ} \mathrm{N}, 114.42^{\circ} \mathrm{W}\right)$. The river was probably one of the northerly flowing streams that discharge near Peddie Point, east of Cape James Ross. This tusk has been mentioned many times in the literature without a specific record of who collected it, or where and when it was collected (Appendix 3). Collagen samples 


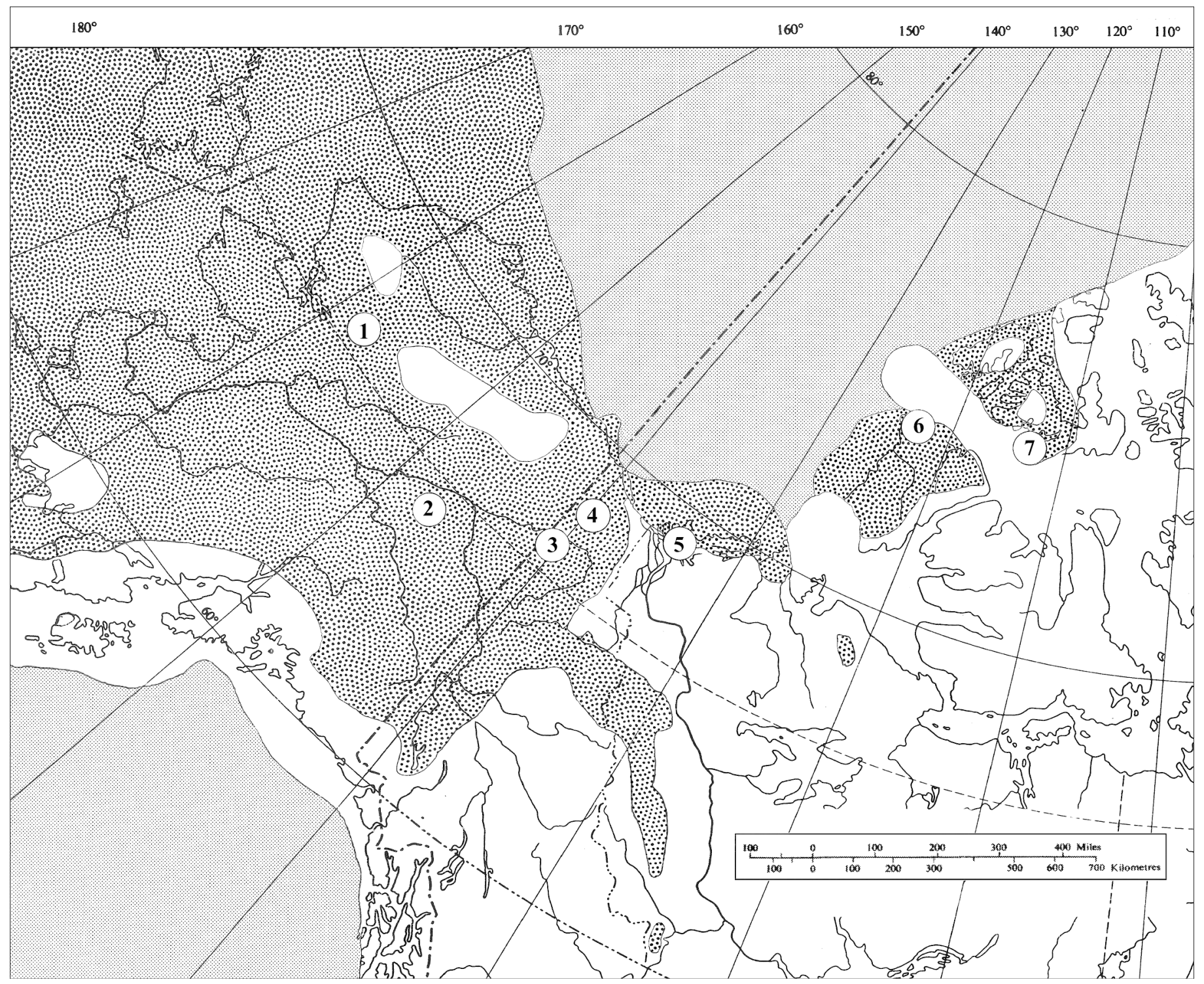

FIG. 2. Map showing some Last Glacial Maximum mammoth sites from Eastern Beringia (modified from 18000 BP map in Dyke et al., 2004). Key: 1. Epiguruk, Alaska; 2. Fairbanks area, Alaska; 3. Bluefish Caves, Yukon; 4. Old Crow Basin, Yukon; 5. Tununuk, Northwest Territories; 6. Ballast Brook area, Banks Island, Northwest Territories; 7. Cape James Ross area, Melville Island, Northwest Territories. Radiocarbon dates for each are given in the text. Palest gray areas represent sea or sea ice, dark gray areas represent 'herb tundra,' and white areas represent glacial ice (in places, ice shelf).

from the specimen were radiocarbon-dated to $21000 \pm$ $320 \mathrm{BP}(\mathrm{GSC}-1760)$ and $21600 \pm 230 \mathrm{BP}(\mathrm{GSC}-1760-2)$ (Blake, 1987). It is the most northerly record for North America. The northernmost woolly mammoth remains in the world are from October Revolution Island $\left(79.30^{\circ} \mathrm{N}\right.$, $98.00^{\circ} \mathrm{E}$ ), north of the Taimyr Peninsula, Siberia (Kuzmin et al., 2003). Interestingly, radiocarbon dates from two different specimens found there- $\mathrm{a}$ tusk and a molar, like the specimens from Banks and Melville islands-have yielded LGM ages of $19970 \pm 110$ BP (LU-688) and $19270 \pm 130$ BP (LU-654B), respectively. Other dates from October Revolution Island range from $25030 \pm$ $210 \mathrm{BP}$ (LU-749B) for a bone to $11500 \mathrm{BP}$ (LU-610) for a tusk (Mol et al., 2003).

The two specimens from Arctic Canada most likely represent woolly mammoths that moved northeastward from the Mackenzie Delta region during the LGM, when worldwide sea level was lowered by $100 \mathrm{~m}$ or probably more (see Appendix 1), exposing large tracts of former seabed off the present Beaufort Sea coast and west of the existing coast of Banks Island. Banks Island was largely clear of ice during the last glaciation (Craig and Fyles, 1960; Dyke and Prest, 1986; Dyke et al., 2003) and was characterized by herb tundra rich enough to supply the needs of these large animals (Dyke et al., 2004).

The main difficulty for mammoths entering Banks and Melville islands from the southwest would have been crossing relatively flat, or slightly undulating ice shelvesa maximum of about $150 \mathrm{~km}$ between the Beaufort landmass ("Beaufortia"?) and southern Banks Island and $100 \mathrm{~km}$ between northern Banks Island and southwestern Melville Island. These calculations are based on a map for 


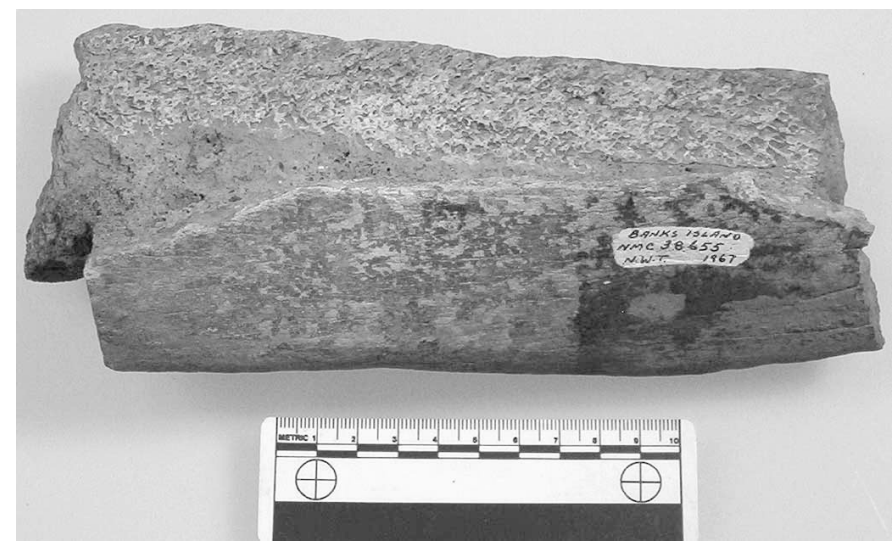

FIG. 3. Left tibia shaft (CMN 38655) of a mammoth from the Ballast Brook area, northwestern Banks Island, Northwest Territories. It yielded a radiocarbon age of $20700 \pm 270 \mathrm{BP}$ (T0-2355, normalized).

18000 BP (Dyke and Prest, 1986). If the animals had reached these areas several thousand years earlier, perhaps aprons of vegetated sediment in front of the advancing Laurentide ice might have made travel across these zones easier, particularly in the shallower depression between Beaufortia and Banks Island. A possible analogue is the crossing-by mammoths (Mammuthus sp.), American mastodons (Mammut americanum), helmeted muskoxen (Bootherium bombifrons), bison (Bison sp.) and other mammals - of large vegetated floodplains that evidently filled the Strait of Georgia about 30000 to $20000 \mathrm{BP}$ in front of southerly moving glacial ice (Harington, 1975, 1996). Further, mammoths could have crossed sea ice, if it was thick enough. An added inducement to cross ice could have been the scent of distant vegetation carried on winds from the northeast. Tundra muskoxen are known to travel between various Canadian Arctic Islands across frozen sea ice at present (Miller et al., 1977).

In any case, evidence with the fossils indicates that mammoths actually lived on what are now Banks and
Melville (but see Appendix 2) islands. Indeed, tundra muskoxen (Ovibos moschatus) evidently reached what is now western Banks Island before 34000 BP (S-288) (Maher, 1968; Harington, 1978; Vincent, 1989), and it is known that they lived, perhaps somewhat earlier (40220 670 BP, Beta-173287), in the vicinity of McKinley Bay, Northwest Territories $\left(69.90^{\circ} \mathrm{N}, 131.17^{\circ} \mathrm{W}\right)$-a possible source area (Harington, 2003:464). But the Banks Island age could be much older than that from McKinley Bay.

It is worth noting that LGM mammoths are relatively common closer to the heart of Eastern Beringia, in Alaska, Yukon, and the Mackenzie Delta area of the Northwest Territories-a likely source region for the Banks and Melville island mammoths. Examples are radiocarbon-dated specimens (Harington, 2003:393-397; Fig. 2) from Epiguruk, Alaska (19060 \pm 90 BP, USGS-1439); the Fairbanks area, Alaska (21 $300 \pm 1300$ BP, L-601); Bluefish Caves, Yukon (20230 \pm 180 BP, RIDDL-223); Old Crow Basin, Yukon (22600 \pm 600 BP, I-3573); and Tununuk, Northwest Territories (19440 $\pm 290 \mathrm{BP}, \mathrm{I}-8578)$.

\section{CONCLUSIONS}

1. Two radiocarbon-dated mammoth fossils (presumably from woolly mammoth, Mammuthus primigenius) from northwestern Banks Island and southwestern Melville Island not only are the northernmost specimens in North America, but indicate that the Mammoth Steppe and Beringia extended eastward at least to $123.1^{\circ} \mathrm{W}$ and possibly to $114.4^{\circ} \mathrm{W}$ during the LGM.

2 . These two specimens probably represent woolly mammoths that moved northeastward from the Mackenzie Delta region during the LGM, when worldwide sea level had dropped about $120 \mathrm{~m}$, exposing large tracts of sea bottom off the Beaufort Sea coast and the west coast of Banks Island (then largely clear of glacial ice). This

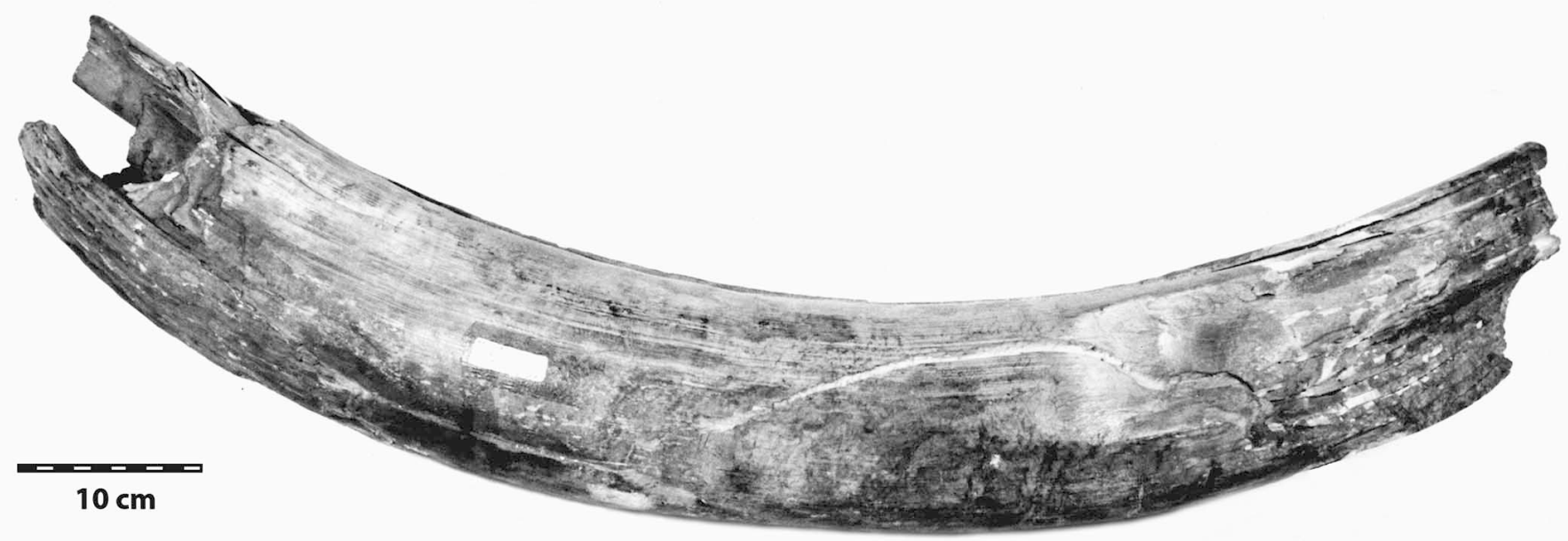

FIG. 4. Partial tusk of a mammoth (CMN 11833) from near Cape James Ross, Melville Island, Northwest Territories. It yielded radiocarbon ages of $21000 \pm 320$ $\mathrm{BP}$ (GSC-1760) and $21600 \pm 230 \mathrm{BP}$ (GSC-1760-2). It is the northernmost record of mammoths in North America. 
hypothetical route may have involved crossing flattish to slightly undulating ice shelves between the previously mentioned Beaufort landmass and southern Banks Island and between northern Banks Island and southwestern Melville Island, if indeed mammoths had not crossed sea ice or vegetated aprons of sediment fronting the advancing ice in those areas prior to $22000 \mathrm{BP}$.

3. These data indicate that the LGM Mammoth Steppe extended from England at least to northwestern Banks Island. Furthermore, Beringia (LGM) had its easternmost limit in that vicinity too, considering that a route for one of the main large Pleistocene mammal indicators (the woolly mammoth) of that refugium evidently existed between the Mackenzie Delta region and that area about $22000 \mathrm{BP}$ or earlier.

4. I propose that the term "Beringia" be used in a broader sense, rather than being applied to a specific, geographically limited refugium that existed particularly during the Late Pleistocene, when spreading of the world's ice sheets caused eustatic drops in sea level. In this broader meaning, "Beringia" should be used wherever evidence exists for the presence of a Bering Isthmus, regardless of its supposed cause(s) and westerly or easterly limits - the focus being on the isthmian link. It is also proposed that the term be used in a standardized way, with its geological age following in parentheses: e.g. "Beringia (Late Cretaceous, $70 \mathrm{Ma}$ )," "Beringia (Early Pliocene, $5 \mathrm{Ma}$ )," "Beringia (Last Glacial Maximum)." Furthermore, the term "isthmus" ('a narrow strip of land connecting two larger land areas,' MerriamWebster Inc., 1985) seems preferable geographically to the commonly used "land bridge," which suggests a construction designed to provide a path or road over water, a depression, or some other obstacle. Thus, I suggest "Bering Isthmus" rather than "Bering Land Bridge."

\section{ACKNOWLEDGEMENTS}

I am particularly grateful to Dr. L.V. Hills (University of Calgary) for donating the specimen from Banks Island to the Canadian Museum of Nature (CMN) and for providing background information. Dr. Hills received support from the Natural Sciences and Engineering Research Council of Canada, the Geological Survey of Canada, and the Polar Continental Shelf Project. I thank Dr. David Gray for his research on the Canadian Arctic Expedition of 1913-18, which turned up important details about the discovery of the mammoth tusk from Melville Island; Dr. A.S. Dyke (Geological Survey of Canada) for his valuable comments on a draft of this manuscript; Dr. W. Blake, Jr., Dick Mol, and an anonymous reviewer for their constructive comments; Gail Harington for wordprocessing and assistance with the figures; and Noel Alfonso $(\mathrm{CMN})$ for finding a suitable circumpolar base map.

\section{APPENDIX 1: \\ DEFINITION OF THE LAST GLACIAL MAXIMUM AND COMMENTS ON SEA-LEVEL DEPRESSION IN THE BERING ISTHMUS \\ AND BEAUFORT SEA AREAS AT THAT TIME}

The Last Glacial Maximum has been defined in many ways. Bradley (1999) and John (1979) state that it is centred on $18000 \mathrm{BP}$, whereas Geotcheus and Birks (2001) give it a broader range, from 28000 to $14000 \mathrm{BP}$. Dyke (1999), focusing on Devon Island, defines the LGM as the time interval of generally maximum ice extent during marine isotope stage 2 (about 25000 to $15000 \mathrm{BP}$ according to Bradley, 1999: Fig. 6.12). For this study, I follow Dyke's definition.

Sea level dropped nearly $100 \mathrm{~m}$ in Beringia during that period, according to Hopkins (1982: Fig. 3C). However, more recent estimates indicate a greater depression: e.g., approximately $130 \mathrm{~m}$ (Elias, 1995: Fig. II.3) and $120 \mathrm{~m}$ for Beringia (Elias, 2005). S.M. Blasco (pers. comm. 2005), who has studied the marine geology of the Beaufort Sea extensively, estimates a drop of $120 \mathrm{~m}$ for that region, and I follow his lead in this paper.

\section{APPENDIX 2: \\ DISCOVERY OF THE MELVILLE ISLAND TUSK AND COMMENTS ON ITS GEOLOGICAL CONTEXT}

Details from Aarnout Castel's diary for Thursday, September 14, 1916 (National Archives of Canada MG30 B10) on the discovery of the tusk (CMN 11833) follow: "The four of us [Castel, Split, Pete, Storkerson] brought the two sledes [sic] into camp. Coming along the river I found a piece of mastodon or mammoth tusk about 2 feet $[0.6 \mathrm{~m}]$ long and 6 inch $[15 \mathrm{~cm}]$ diameter." This passage suggests that the tusk was found near their camp-presumably on the coast near Peddie Point, for Noice (1924:201) mentions the base camp under the name "Commander at Peddie Point" - not far up a stream leading to that locality. Stefansson (1918:355) confirms this position of their camp on southern Melville Island by stating that it was "on the Dundas Peninsula side of Liddon Gulf about 15 miles [24 km] northeast of Cape James Ross and a mile [1.6 km] inland." The only Pleistocene deposits mapped in the vicinity (GSC Map 1583A in Hodgson et al., 1984) are deltaic deposits of gravel, sand, or silt ("5") perhaps originating from glacial lakes. The Liddon Till occurs just east of this site. It was deposited by the last ice entering Liddon Gulf from M'Clure Strait. In the chronology of Banks Island, ice last filled M'Clure Strait in the M'Clure Stade (the penultimate stade) of Early Wisconsinan age of the Amundsen Glaciation (the last glaciation) (Hodgson et al., 1984:24). Therefore, the Liddon till would have been deposited well before mammoths, represented by the tusk, lived in the area. 
However, it is worth noting that the Quaternary geologist Dr. John England (pers. comm. 2005), having worked around Dundas Peninsula during the summers of 2002 to 2004, has not seen any evidence yet for deposits recording ice-free conditions on Dundas Peninsula during the LGM. He has the strong impression that during the LGM Laurentide ice crossed the entire peninsula. Further, his work shows that relative sea level during deglaciation of Dundas Peninsula was about 70 $\mathrm{m}$ or higher above present. This unpublished evidence suggests that the tusk may not represent a mammoth that actually lived on Melville Island.

\section{APPENDIX 3: EARLIER REFERENCES TO THE MELVILLE ISLAND TUSK}

The tusk (CMN 11833), has been mentioned often, but without specific details of its locality, collector, and date of collection. Blake (1974) searched V. Stefansson's 1916 diary without finding a reference to it. However, Blake noted that on 15 April 1917, while on Borden Island, Stefansson wrote a letter to Captain H. Gonzales, who was then visiting the base camp near Liddon Gulf, Melville Island, requesting that "the scientific specimens, including the mammoth" should be taken to the ship Polar Bear, which was at winter quarters in Victoria Island. A typed letter in the CMN Archives from J. Hadley to V. Stefansson, dated 1918, mentions on p. 2 "part of a mammoth tusk from the north" sent to the Polar Bear from the sled party. Later Stefansson (1918:362) reported "We found a tusk, but no other mammoth remains in Melville Island."

The tusk fragment was first described by Kindle (1924:183185), who incorrectly stated that it "was found on Banks Island, about latitude $72^{\circ}$." In the Geological Survey of Canada Library copy of the publication, someone (perhaps Kindle?) crossed out "Banks," writing "Melville" above it, and replacing " $72^{\circ}$ " with " $75^{\circ}$." Kindle noted that the find "extended considerably the previously known range of the mammoth in the circumpolar region" and stated that besides being excellently preserved, it was 36 inches $[91 \mathrm{~cm}]$ long with a basal diameter of 5.75 inches $[15 \mathrm{~cm}]$, "which would indicate a total length of ten feet [3 $\mathrm{m}]$ or more." He also figured the specimen for the first time, noting that it was found by the Canadian Arctic Expedition under the command of V. Stefansson in 1916. In the same year, Hay (1924:121) mentioned that Kindle had informed him of "the discovery of the tusk of an elephant on Melville Island, at the head of Liddon Gulf... in latitude $75^{\circ}$." He continued: "The animal probably belonged to the species known as Elephas primigenius $[=$ Mammuthus primigenius, the woolly mammoth], possibly Depéret's form sibericus." Farrand (1961:735) refers to Kindle's paper, repeating the error that the tusk was from Banks Island rather than Melville Island.

Blake (1987:20) reported that the tusk fragment "probably collected near Cape James Ross, Melville Island, Northwest Territories, in 1916 by the Northern Party of the
Canadian Arctic Expedition" was radiocarbon-dated at $21600 \pm 230 \mathrm{BP}$ (GSC-1760-2), an earlier determination being $21900 \pm 320$ BP (GSC-1760). Blake (1987:20) quoted Harington's comment on these dates: "It is difficult to explain the presence of mammoths in this part of the Queen Elizabeth Islands near the peak of the Wisconsinan glaciation...perhaps the tusk was transported from a refugium to the southwest by glacial ice, sea ice or, less likely, by man.” Harington (1971, 1978, 1986, 1990) mentioned the tusk several times, figuring it in the last reference. Agenbroad (1984) and Agenbroad and Barton (1991:28) also mentioned the specimen in review papers.

\section{REFERENCES}

AGENBROAD, L.D. 1984. New World mammoth distribution. In: Martin, P.S., and Klein, R.G., eds. Quaternary extinctions. Tucson: University of Arizona Press. 90-108.

AGENBROAD, L.D., and BARTON, B.R. 1991. North American mammoths: An annotated bibliography 1940-1990. The Mammoth Site of Hot Springs, South Dakota. Scientific Paper 2. $118 \mathrm{p}$.

BLAKE, W., Jr. 1974. Studies of glacial history in Arctic Canada. II. Interglacial peat deposits on Bathurst Island. Canadian Journal of Earth Sciences 11(8):1025-1042.

. 1987. Geological Survey of Canada radiocarbon dates XXVI. Geological Survey of Canada Paper 86-7. 60 p.

BRADLEY, R.S. 1999. Paleoclimatology: Reconstructing climates of the Quaternary. 2nd ed. San Diego: Harcourt, Academic Press.

CRAIG, B.G., and FYLES, J.G. 1960. Pleistocene geology of Arctic Canada. Geological Survey of Canada Paper 60 - 10.21 p.

DAWSON, G.M. 1894. Geological notes on some of the coasts and islands of Bering Sea and vicinity. Geological Society of America Bulletin 5:117-146.

DYKE, A.S. 1999. Last Glacial Maximum and deglaciation of Devon Island, Arctic Canada: Support for an Innuitian Ice Sheet. Quaternary Science Reviews 18(1999):393-420.

DYKE, A.S., and PREST, V.K. 1986. Paleogeography of northern North America 18 000-12 000 years ago. Geological Survey of Canada Map 1703A (18 000 years before present).

DYKE, A.S., MOORE, A., and ROBERTSON, L. 2003. Deglaciation of North America. Geological Survey of Canada, Open File 1574. [Thirty-two maps at 1:7000000 scale with accompanying digital chronological database and one poster (in two sheets) with full map series.]

DYKE, A.S., GIROUX, D., and ROBERTSON, L. 2004. Paleovegetation maps, northern North America, 18000 to 1000 BP. Geological Survey of Canada, Open File 4682. [Paper poster or CD release with 15 maps at 1:7 500000 scale, shape and PDF files and digital databases with radiocarbon-dated pollen, macrofossil, and terrestrial mammal sites.]

ELIAS, S.A. 1995. The ice-age history of Alaskan National Parks. Washington: Smithsonian Institution Press.

2005. Beringia. In: Nuttall, M., ed. Encyclopedia of the Arctic. New York: Routledge. 238. 
FARRAND, W.R. 1961. Frozen mammoths and modern geology. Science 133(3455):729-734.

GOETCHEUS, V.G., and BIRKS, H.H. 2001. Full-glacial upland tundra vegetation preserved under tephra in the Beringia National Park, Seward Peninsula, Alaska. Quaternary Science Reviews 20(2001): 135-147.

GUTHRIE, R.D. 1990. Frozen fauna of the mammoth steppe. Chicago: University of Chicago Press.

HARINGTON, C.R. 1971. Ice age mammals in Canada. Arctic Circular 22:66-89.

1975. Pleistocene muskoxen (Symbos) from Alberta and British Columbia. Canadian Journal of Earth Sciences 12(6): 903-919.

. 1978. Quaternary vertebrate faunas of Canada and Alaska and their suggested chronological sequence. Syllogeus 15 . $105 \mathrm{p}$.

1981. Pleistocene saiga antelopes in North America and their paleoenvironmental implications. In: Mahaney, W.C., ed. Quaternary paleoclimate. Norwich, England: Geo Abstracts Ltd. 193-225.

1986. The impact of changing climate on some vertebrates in the Canadian Arctic. In: French, H.M., ed. Proceedings of a Canadian Climate Program Workshop on Impact of Climatic Change on the Canadian Arctic, 3-5 March 1986, Orillia, Ontario. 100-113.

1990. Ice age vertebrates in the Canadian Arctic Islands, In: Harington, C.R., ed. Canada's missing dimension: Science and history in the Canadian Arctic Islands, Vol. 1. Ottawa: Canadian Museum of Nature. 140-160.

1996. Quaternary animals: Vertebrates of the ice age. In: Ludvigsen, R., ed. Life in stone: A natural history of British Columbia's fossils. Vancouver: UBC Press. 259-273.

- ed. 2003. Annotated bibliography of Quaternary vertebrates of northern North America - with radiocarbon dates. Toronto: University of Toronto Press.

HARINGTON, C.R., and CINQ MARS, J. 1995. Radiocarbon dates on saiga antelope (Saiga tatarica) fossils from Yukon and Northwest Territories. Arctic 48(1):1-7.

HAY, O.P. 1924. The Pleistocene of the middle region of North America and its vertebrated animals. Carnegie Institute of Washington Publication No. 322a. 385 p.

HODGSON, D.A., VINCENT, J.-S., and FYLES, J.G. 1984. Quaternary geology of central Melville Island, Northwest Territories. Geological Survey of Canada Paper 83-16. 25 p.

HOPKINS, D.M., ed. 1967. The Bering Land Bridge. Stanford: Stanford University Press.

- 1982. Aspects of the paleogeography of Beringia during the Late Pleistocene. In: Hopkins, D.M., Matthews, J.V., Jr., Schweger, C.E., Young, S.B., and Stanley, V., eds. Paleoecology of Beringia. New York and London: Academic Press. 3-28.

HOPKINS, D.M., MATTHEWS, J.V., Jr., SCHWEGER, C.E., YOUNG, S.B., and STANLEY, V., eds. 1982. Paleoecology of Beringia. New York and London: Academic Press.

HULTÉN, E. 1937. Outline of the history of arctic and boreal biota during the Quaternary. Stockholm: Bokförlagsaktiebolaget Thule.
JOHN, B.S. 1979. The winters of the world: Earth under the ice ages. New York: Halsted Press.

JOHNSTON, W.A. 1933. Quaternary geology of North America in relation to the migration of man. In: Jenness, D., ed. The American aborigines: Their origin and antiquity. Toronto: University of Toronto Press. 11-45.

KINDLE, E.M. 1924. Note on a mammoth tusk from the Arctic Archipelago (Article 12). American Journal of Science 7(207):183-185.

KUZMIN, Y.V., ORLOVA, L.A., and ZOLNIKOV, I.D. 2003. Dynamics of the mammoth (Mammuthus primigenius) population in northern Asia: Radiocarbon evidence. In: Reumer, J.W.F., de Vos, J., and Mol, D., eds. Advances in mammoth research. Deinsea 9:221-237.

MAHER, W.J. 1968. Muskox bone of possible Wisconsin age from Banks Island, Northwest Territories. Arctic 21(4):260-266.

MATTHEWS, J.V., Jr. 1982. East Beringia during Late Wisconsin time: A review of the biotic evidence. In: Hopkins, D.M., Matthews, J.V., Jr., Schweger, C.E., Young, S.B., and Stanley, V., eds. Paleoecology of Beringia. New York and London: Academic Press. 127-150.

MERRIAM-WEBSTER INC. 1985. Webster's ninth new collegiate dictionary. Springfield, Massachusetts: Merriam-Webster Inc.

MILLER, F.L., RUSSELL, R.H., and GUNN, A. 1977. Distributions, movements and numbers of Peary caribou and muskoxen on western Queen Elizabeth Islands, Northwest Territories, 1972-74. Canadian Wildlife Service, Report Series 40. 55 p.

MOL, D., TIKHONOV, A.N., VAN DER PLICHT, J., and BOLSHIYANOV, D.Y. 2003. Discoveries of woolly mammoth, Mammuthus primigenius (Proboscidea: Elephantidae) and some other Pleistocene mammals on the Taimyr Peninsula. Russian Journal of Theriology 2(2):77-95.

MORLAN, R.E. 1996. Beringia. Beringian Research Notes No. 9:1 -4. Whitehorse: Heritage Resources Unit, Yukon Business, Tourism and Culture.

NOICE, H. 1924. With Stefansson in the Arctic. New York: Dodd, Mead.

O'NEILL, D. 2004. The last giant of Beringia: The mystery of the Bering Land Bridge. Boulder, Colorado: Westview Press.

SHER, A.V. [1976] 1984. The role of Beringian land in the development of Holarctic mammalian fauna in the Late Cenozoic. In: Kontrimavichus, V.L., ed. Beringia in the Cenozoic era. New Delhi: Amerind Publishing Company. 296-316. (Originally published in Russian.)

- 1997. Beringida: Land, sea, and the evolution of cryoxeric environments and faunas. In: Brigham-Grette, J., and Elias, S.A., eds. Beringian Palaeoenvironments Workshop, 20-23 September 1997, Florissant, Colorado, Program and Abstracts. $145-148$.

STEFANSSON, V. 1918. The activities of the Canadian Arctic Expedition from October, 1916, to April, 1918. Geographical Review 6:354-369.

U.S. NATIONAL OCEANOGRAPHIC AND ATMOSPHERIC ADMINISTRATION. 2004. Beringian atlas home page: The Beringian environment. www.ncdc.noaa.gov/paleo/parcs/atlas/ Beringia/research.html. Accessed 6 August 2005. 
VINCENT, J.-S. 1989. Quaternary geology of the northern Canadian Interior Plains. In: Fulton, R.J., ed. Quaternary geology of Canada and Greenland. Geology of Canada No. 1. Ottawa: Geological Survey of Canada. 100-137.

WALTARI, E., DEMBOSKI, J.R., KLEIN, D.R., and COOK, J.A. 2004. A molecular perspective on the historical biogeography of the northern high latitudes. Journal of Mammalogy 85(4): $591-600$.
YURTSEV, B.A. 1974. Problemy botanicheskoy geografii severovostochnoy Azii (Problems of phytogeography of northeastern Asia). In Russian. Leningrad: Nauka.

. 1984. Problems of the Late Cenozoic paleogeography of Beringia in the light of phytogeographic evidence. In: Kontrimavichus, V.L., ed. Beringia in the Cenozoic Era. Vladivostok: Academy of Sciences of the USSR, Far-Eastern Scientific Center. 129-153. 